\title{
Effectiveness of Teaching in Blended Mode: A Case Study from Sri Lankan University System
}

\author{
Ruwini Prasadini Dharmawardene, Lishanthi Wijewardene \\ Faculty of Management Studies and Commerce, University of Sri Jayewardenepura, Nugegoda, Sri Lanka \\ Email: prasadini@sjp.ac.lk, lishanthi@sjp.ac.lk
}

How to cite this paper: Dharmawardene, R.P. and Wijewardene, L. (2021) Effectiveness of Teaching in Blended Mode: A Case Study from Sri Lankan University System. Open Access Library Journal, 8: e7883. https://doi.org/10.4236/oalib.1107883

Received: August 23, 2021

Accepted: September 13, 2021

Published: September 16, 2021

Copyright $\odot 2021$ by author(s) and Open Access Library Inc.

This work is licensed under the Creative Commons Attribution International License (CC BY 4.0).

http://creativecommons.org/licenses/by/4.0/

\begin{abstract}
Undergraduates in the University of Sri Jayewardenepura in Sri Lanka find it challenging to achieve the outcome of improving business presentation skills during their one-year Intensive English Course. In this study, we explored whether different delivery modes (of face-to-face, online and blended) influenced this outcome achievement. Three tutors with the same level of qualifications and service record were employed to evaluate the three groups of students $(\mathrm{N}=180)$ who practised thirty sessions of business presentations in the face-to-face, online and blended modes in four batches from 2017 to 2020. A pre-test and a post-test were conducted to assess presentation skills. The online group received their training fully online with no face-to-face hours while the blended group received $70 \%$ of their practice online, with $30 \%$ in the physical classroom. The three groups showed the performance improvements as Blended mean difference $=8.933$, Online mean difference $=$ 2.000 and the face-to-face mean difference $=5.267$ showing a significant improvement in the blended mode group indicating an association between the mode of learning and presentation skills which will be of use for the Business Communication course developers in Sri Lanka in the future. This study, with further confirmatory evidence, can have implications for improving Business English presentation skills in the context of enhancing communication skills in higher education.
\end{abstract}

\section{Subject Areas}

Language and Communication, Online Learning

\section{Keywords}

Online Learning, Blended Learning, Presentation Skills, Face-to-Face Learning, Business Communication 


\section{Introduction}

Presentation skills have become crucial for working adults in Sri Lanka at present than at any other time. Although some business professionals are with great abilities and intelligence, they are usually judged in their society on how well they make presentations. Targeting undergraduates, all 16 state universities in the country have started offering English or Business Communication courses. Many of those courses are designed to equip undergraduates with business presentation skills and expect students to improve their public speaking skills as well. Most of those courses are conducted in a face-to-face mode in traditional classroom settings while a few of them are conducted in fully online mode. This study investigated how effective it would be if a blended mode of delivery was introduced instead of fully online or face-to-face modes of delivery in Business Communication courses to practice presentation skills in the university system of Sri Lanka.

\section{Literature Review}

Although technology-aided instruction can contribute to the improvement of English as a Second Language (ESL) students' proficiency [1], the traditional face-to-face teaching is still reported to be able to outperform online teaching because it attracts and creates interest in students [2]. However, according to Driscoll [3], the blended learning model, which is a mode of delivery that combines online digital media with traditional classroom methods can be successfully applied to adults' learning in many disciplines.

It has been concluded through numerous surveys and reports that communication is one of the most important skills for career success [4]. According to the GMAC [5] Corporate Recruiters Survey Report, communication skills rank highest among the skills employers consider most important, followed by teamwork, technical skills, leadership skills, and managerial skills. Employers are likely to choose job candidates with soft skills over those with hard/technical skills [4] [6] and many business leaders expect higher learning institutions to develop the communication skills of their students and provide them with internship and practical experience opportunities before they graduate [7]. As a result of understanding the importance of communication skills for the success of their students in the long term, many business schools include the development of these skills in their curriculum [8] [9] [10]. As such, it has been reiterated that communication skills (oral, written, listening, and interpersonal) are critical for productive performance in a professional environment, and many employers look for communication skills in their new recruits. However, it has been reported by employers and recruiters that many recent business graduates come to the workplace lacking communication skills [10] [11], even though they have adequate hard skills [3] [12].

The concept of communication in the business world is broad and complex with different levels, such as individual, group, and organizational communica- 
tion [13]. Since communication can be general that can draw from many disciplines, business communication can be interpreted as including business writing, business English, presentation skills, marketing communication, intercultural communication, and negotiation [14]. Communication skills are critical for productive performance in a professional workplace, and many employers look for the skills in their new hires [15].

Strong communication skills have been seen as imperative in almost all facets of life. The ability to communicate clearly and succinctly has become one of the most important skills one can improve, given the constant meetings, presentations, emails, conferences, and networking events in the modern business setting. Young and Murphy [16] reveal that business education should be sensitive to the communication skills needs of business employees [17], written communication skills closely succeeding the problem-solving skills, and the ability to work in teams-belong to the top three attributes that employers look for in a candidate's resume. Chen, Yao, and Kotha's [18] study focuses on only two specific aspects of the impression made by a presentation-the perceived passion and the preparedness of the presenter. Business English or business communication is a rapidly growing field within the area of English Language Teaching and English for Specific Purposes (ESP) [19]. According to Dudley-Evans and John [20], English for specific purposes, which is related to specific disciplines, is designed to meet the specific needs of the learner. Oral presentation skills are essential for employability and academic study because they lead students to enter into debate and sustained reasoning. They also enable students to participate fully in their learning, demonstrate their ability to communicate, and help them prepare for their future work [21]. However, as educational environments have changed with the rapid development of technology, especially during the COVID-19 pandemic, for EFL students, it seems to be quite challenging to make effective oral presentations without face-to-face communication between the presenters and the audience. Therefore, in online education, the students may require more presentation training practice where explicit, immediate, and systematic feedback from external sources (such as experts and peers) could be provided [22].

We live in a society today, where technology has become a necessary tool that is required for presenting information and improving of key competencies of the students, for work, education, information, and contacts, and where e-learning activities are a necessary part of the living style of the present young generation [23]. The ability to present information effectively is an important skill that higher education students should master [24]. Good presentation skills also offer a particularly competitive advantage to students in business English majors, because it is an essential quality for career success [25]. Businesses expect employees to have strong communication and presentation competencies to be effective in their jobs. Producing employable graduates has become an important criterion in higher education [26]. Although students in traditional face-to-face programs have opportunities to practice presentation skills, the growth of online 
curricula creates issues with providing students the opportunities to develop oral skills. Online presentation tools exist but mastering the technology may be difficult and requires careful planning, design, and implementation to be effective [27].

According to [28], education experts and employers stress that most undergraduates enter the job market without mastering good oral communication competence, and therefore it is urgent that the training of students' oral presentation skills be incorporated into higher education [29]. In recent years, a few scholars have started to investigate the impact of multimedia on the development of student's oral presentation skills They found that the intervention of multimedia could indeed enhance a student's performance, but aspects such as eye contact and the use of filled pauses received progress only with teacher assistance, indicating the important role of teachers in oral presentation training, especially in a multimodal context [22].

Business Communication has been defined as sending and receiving of verbal and non-verbal messages within the organizational context [30] [31] [32]. This definition was expanded further, indicating that business communication is a process of generating, transmitting, receiving, and interpreting messages in interpersonal, group, public, and mass communication contexts through written and verbal formats [33]. Hynes [34] stated that effective business communication is the key to planning, leading, organizing, and controlling the resources of the organizations to achieve objectives, and may be formal or informal in nature whilst Argenti [35] discussed the functional aspects of business communication, highlighting that business communication functions include media relations, online communications, marketing, special events, product/brand communications, crisis management, employee/internal communications, community relations, and product/brand advertising. Hence the expanse and importance of business communication underscore the need for business education and business to collaborate in preparing business majors for the workplace [36].

Presentation skills have gained attention both in higher education and among business trainers, as they constitute one of the core competencies of a professional [37]. Effective communication skills are a sign of professionalism and should be addressed as a key competency by educational institutions [38]. Oral presentations are seen as one of the most important forms of public speaking [39]. Courses aimed at teaching oral presentation skills are traditionally conducted in a face-to-face environment, despite the remarkable growth of online learning that has occurred in higher education. Many researchers highlight an increased demand for online programs in the field of higher education although few institutions are ready to offer this model to their students [40]. Undergraduates must hone their English language skills in the journey of becoming marketable graduates in a competitive business environment [41] and making oral presentations is one of the important components of an English for Academic Purposes (EAP) course [42]. The importance of preparing college graduates for effective oral presentation and writing skills has been felt as academic and pro- 
fessional surveys have demonstrated the consistency of opinion that newly hired or recruited college graduates lack the presentation skills for managerial or administrative positions [43]. These concerns about inadequate academic preparation and skills deficiency in communication for performing major tasks were also identified in many research studies [44] according to Ephraim [43]. Ephraim [43] also pointed out that earlier studies [31] revealed the impact of inadequate communication skills among employees and college graduates and stressed the obvious need for interpersonal skills for business graduates seeking employment in business and marketing environments. Academic researchers [45] [46] and institutional studies [47] have re-evaluated the critical importance of interpersonal communication in domestic and global organizations. These studies have determined that interpersonal competence greatly improves a candidate's competitive advantage in obtaining a position as well as improving the operations of business [43]. This is especially critical for graduate students and for employees in the process of changing jobs or applying for new or higher positions in organizations.

The increasing growth of online learning creates opportunities for language learners to improve their academic proficiency. However, quite often, foreign language educators claim that an online learning environment is not suitable for developing students' oral speaking proficiency [48]. Kenkel [39] points out that online business courses often eliminate oral presentations from their curricula, which creates a serious void in a student's educational experience, although academics and practitioners have long agreed that communication skills are linked to professional effectiveness. Russ [9] concluded that faculty must provide students with the communication skills demanded by employers. Campbell [49] found that oral presentations skills must be mastered to have a successful professional life; Grez, Valcke, and Roozen [50] concurred that higher education should address this skill as a key competency, and Kennedy [51] noted research from both business leaders and alumni claiming college graduates often lack adequate oral communication skills. Cronin and Glen [52] confirmed this deficiency.

Graham [53] defined "blended learning systems" as learning systems that combine face-to-face instruction with computer-mediated instruction. Poon [54] adds that the two delivery methods aim to complement each other. Currently, the use of the term blended learning involves combining Internet and digital media with established classroom forms that require the physical co-presence of teachers and students [55]. The concept of blended learning works best when planned, and proactive measures are taken to look into the problems that a teacher will encounter [56]. If properly implemented, blended learning can result in improved student success, satisfaction, and retention [57]. As presentation skills are a critical competency for business students, other online teachers should be encouraged to integrate an oral presentation unit into their online courses. Further research is needed to determine how best to incorporate this element so it is taught across the board; however, student comments 
on the end-of-semester evaluations indicate oral communication skills can be successfully taught online. According to Kenkel [39], traditional face-to-face business courses generally include at least one oral presentation in their curriculum, but this is not the case in most online business courses. Despite the documented importance of oral presentation skills, faculty often eliminates this component when business courses are taught online. The difficulty of teaching presentation skills online is one of the obstacles to developing an effective online business communication course. Kenkel [39] further reiterates that, given the rapid growth in online programs, this deficiency could have serious consequences for business graduates.

A business presentation is usually evaluated by the following criteria: structure (introduction, conclusion, and organization), vocal qualities, extra-linguistic features (eye contact, body language, appearance of the speaker), and visuals [39]. As Kenkel [39] further elicited, online business communication courses should require students to prepare and present professional presentations. In addition, all online courses should consider adding such an element to teach professional speaking across the curriculum. The technology is readily available and proven pedagogy can easily be implemented to effectively accomplish this task. Kenkel [39] further points out that, as online courses continue to be scrutinized for quality, important skills such as oral presentations can no longer simply be overlooked or eliminated from the curriculum because it appears too difficult or cumbersome to integrate into the class.

The majority of public speaking courses include online components as well as traditional face-to-face classroom interaction [58]. Blended learning is a valuable concept that can be used to more successfully achieve teaching goals and it allows students to develop and practice English language skills outside the classroom [59]. Wang et al. [60] support the idea that blended learning is the most beneficial means of teaching. Fully online courses tend to neglect one of the most important components of a public speech: the audience [58]. Therefore, Crosthwaite et al. [48] reiterate that classroom-based seminars are seen as a way to provide students with an opportunity to experience real-time communication and focus on its extra-linguistic features (body language, interactive skills, eye contact). The age-old method of lecture or face-to-face interaction does not become irrelevant but needs to be in semblance with the present environment of learning and teaching [56]. In today's world technology has a definitive part in the lives of students be it in the classroom or outside, therefore teaching plans need to have technology and learners need to be adept in them for technology-based skill is a valid and mandatory industry skill [56]. In the coming years as learners and the faculty are going to use and create a semblance of technology it is bound to grow more in the classroom as learning tools [56].

\section{Methodology}

The main objective of this study was to compare undergraduates' performance 
in making business presentations in the blended learning (BL), face-to-face and online modes of delivery in the University of Sri Jayewardenepura in Sri Lanka. The setting was made at the Business Communication Unit in the Faculty of Management Studies and Commerce in the University of Sri Jayewardenepura in Sri Lanka. All the participants and other persons involved were aware of this research and consented in writing for their information to be used. The total sample of this study consisted of 180 students, both male and female, (age: 21 to 23 years) who were randomly selected from the students who entered the Faculty in the years 2017, 2018, 2019 and 2020. The study was conducted in four years taking 45 participants for each year. The students were randomly assigned into three groups, assessed for their pre presentation performance, which was recorded as pre-test scores, and instructed to practise the given presentation topics in three different modes of learning, blended, face-to-face and online over four months. Post assessment was done at the end of the four months period in each year by the same evaluators. The online and blended practising were carried on using a Zoom platform. The students were grouped using Breakout Rooms on Zoom for discussion. The same topics, during the same time were practised by the participants in the face-to-face mode in their physical classrooms. The entirely online group practised their presentations fully online over Zoom and they were not given an opportunity to meet in a physical learning environment. Blended mode group practised $70 \%$ of their assigned time online and the balance $30 \%$ in their face-to-face classrooms.

The study focused on three research questions.

1) What level of achievement is made by the students learning in the face-to-face mode in improving presentation skills?

2) What level of achievement is made by the students learning in the fully online mode in improving presentation skills?

3) What level of achievement is made by the students learning in the blended mode in improving presentation skills?

Pre and posttest were conducted by assigning students to make a presentation on a given topic. Assessment was done by the same three evaluators both at the pre and posttests. Presentation topics were randomly chosen by the researchers from the given list of topics in the students' course manual. The same topic was given to the students in each group and was instructed to prepare for a ten minute-presentation. They were given only 30 minutes to prepare at each test.

After the pretest, the three groups were intervened in three different modes of learning as described in Table 1.

Three Tutors of English who have a similar level of qualifications in teaching and similar number of years in teaching profession were assigned to assess the three groups of students who practised presentations in three different modes at the pre and posttests. In that way their influence on results was guarded. Authors were not evaluators at any stage of the study. The researcher hypothesized the same level of outcome from all three groups at the end of the course. The data was analyzed using paired sample t test in the SPSS Version 22.0. 
Table 1. Strategies used to teach the three groups.

\begin{tabular}{|c|c|c|c|}
\hline \multirow{2}{*}{$\begin{array}{l}\text { Study } \\
\text { Group }\end{array}$} & \multicolumn{3}{|c|}{ Strategies utilized for the three groups in each year } \\
\hline & Course Content & Practicing method & Assessment criteria \\
\hline Online & $\begin{array}{l}\text { Ten topics relevant to annual } \\
\text { budget of a company were } \\
\text { given by the Tutors. }\end{array}$ & $\begin{array}{l}\text { Ten sessions, each with two-hour duration, were } \\
\text { allocated on Zoom. No face-to-face interaction was } \\
\text { allowed. Students were grouped in to three groups } \\
\text { using Breakout Rooms. }\end{array}$ & $\begin{array}{l}\text { Three Tutors assessed each individual before } \\
\text { and after the four months practising period. } \\
\text { Average score was calculated for the online } \\
\text { group. }\end{array}$ \\
\hline Blended & $\begin{array}{l}\text { Same ten topics were } \\
\text { administered. }\end{array}$ & $\begin{array}{l}\text { Seven topics were practised over Zoom while three } \\
\text { topics were practised in the physical classroom. }\end{array}$ & $\begin{array}{l}\text { Three Tutors assessed each individual before } \\
\text { and after the four months practising period. } \\
\text { Average score was calculated for the blended } \\
\text { group. }\end{array}$ \\
\hline $\begin{array}{l}\text { Face- } \\
\text { to-face }\end{array}$ & $\begin{array}{l}\text { Same ten topics were } \\
\text { administered. }\end{array}$ & $\begin{array}{l}\text { Ten sessions, each with two-hour duration, were } \\
\text { allocated in the face-to-face classroom. No online } \\
\text { interaction was allowed for presentation practice. }\end{array}$ & $\begin{array}{l}\text { Three Tutors assessed each individual before } \\
\text { and after the four months practising period. } \\
\text { Average score was calculated for the } \\
\text { face-to-face group. }\end{array}$ \\
\hline
\end{tabular}

\section{Discussion}

The study results show that there is a significant difference between the mean scores of the pre and post tests conducted for each group of participants assessing their presentation skills in all four years. However, the improvement of the participants who practised presentation skills through the mode of blended learning was the highest compared to their counterparts in all four years.

The mean score difference between the pre and post-tests of the blended group is the highest (8.933) in 2017 (Table 2), compared to online (2.000) and face-to-face (5.267) groups.

The mean score difference between the pre and post-tests of the blended group is the highest (4.533) in 2018 (Table 3), compared to online (3.400) and face-to-face (3.800) groups.

The mean score difference between the pre and post-tests of the blended group is the highest (4.667) in 2019 (Table 4), compared to online (1.200) and face-to-face (3.600) groups.

The mean score difference between the pre and post-tests of the blended group is the highest (5.067) in 2020 (Table 5), compared to online (2.000) and face-to-face (3.667) groups.

As shown in Table 6, the overall mean score difference between the pre and post-tests of the blended group is the highest (5.800), compared to the online (2.150) and face-to-face (4.082) groups when all four years were considered.

The results of this study are consistent with the results of a recent study conducted to see the effectiveness of using the blended mode instead of the traditional face-to-face mode in transferring communication skills to pre-university science students in Canada [61]. The results further show that the students in the blended group perform significantly better than their counterparts in the chosen field of study. The findings of a previous study conducted with the same subjects assessing their achievements in business English vocabulary [62] are also consistent with the findings of the present study. 
However, there were some limitations to the study. The sample was limited to 180 participants and the study was conducted only in one university in the country limiting the generalizability in its findings.

Table 2. Paired mean results for the three groups of performance in 2017.

\begin{tabular}{|c|c|c|c|c|c|c|c|c|c|}
\hline & & \multirow{2}{*}{ Mean } & \multirow{2}{*}{$\begin{array}{c}\text { Std. } \\
\text { Deviation }\end{array}$} & \multirow{2}{*}{$\begin{array}{l}\text { Std. Error } \\
\text { Mean }\end{array}$} & \multicolumn{2}{|c|}{$\begin{array}{l}\text { 95\% Confidence Interval of } \\
\text { the Difference }\end{array}$} & \multirow{2}{*}{$\mathrm{t}$} & \multirow[t]{2}{*}{ df } & \multirow{2}{*}{$\begin{array}{c}\text { Sig. } \\
\text { (2-tailed) }\end{array}$} \\
\hline & & & & & Lower & Upper & & & \\
\hline Pair 1 & Online Posttest - Online Pretest & 2.000 & 1.069 & 0.276 & 1.408 & 2.592 & 7.246 & 14 & 0.000 \\
\hline Pair 2 & F2F_PostTest - F2F_PreTest & 5.267 & 2.086 & 0.539 & 4.111 & 6.422 & 9.777 & 14 & 0.000 \\
\hline Pair 3 & Blended_PostT - Blended_PreT & 8.933 & 1.335 & 0.345 & 8.194 & 9.672 & 25.926 & 14 & 0.000 \\
\hline
\end{tabular}

Significance level $\mathrm{p}<0.005$.

Table 3. Paired mean results for the three groups of performance in 2018.

\begin{tabular}{|c|c|c|c|c|c|c|c|c|c|}
\hline & & \multicolumn{5}{|c|}{ Paired Differences } & \multirow{3}{*}{$\mathbf{t}$} & \multirow{3}{*}{ df } & \multirow{3}{*}{$\begin{array}{c}\text { Sig. } \\
\text { (2-tailed) }\end{array}$} \\
\hline & & \multirow{2}{*}{ Mean } & \multirow{2}{*}{$\begin{array}{c}\text { Std. } \\
\text { Deviation }\end{array}$} & \multirow{2}{*}{$\begin{array}{l}\text { Std. Error } \\
\text { Mean }\end{array}$} & \multicolumn{2}{|c|}{$\begin{array}{l}\text { 95\% Confidence Interval of } \\
\text { the Difference }\end{array}$} & & & \\
\hline & & & & & Lower & Upper & & & \\
\hline Pair 1 & Online Posttest - Online Pretest & 3.400 & 5.717 & 1.476 & 0.234 & 6.566 & 2.303 & 14 & 0.037 \\
\hline Pair 2 & F2F_PostTest - F2F_PreTest & 3.800 & 5.130 & 1.324 & 0.959 & 6.641 & 2.869 & 14 & 0.012 \\
\hline Pair 3 & Blended_PostT - Blended_PreT & 4.533 & 4.838 & 1.249 & 1.854 & 7.213 & 3.629 & 14 & 0.003 \\
\hline
\end{tabular}

Significance level $\mathrm{p}<0.005$.

Table 4. Paired mean results for the three groups of performance in 2019.

\begin{tabular}{|c|c|c|c|c|c|c|c|c|c|}
\hline & & \multicolumn{5}{|c|}{ Paired Differences } & \multirow{3}{*}{$\mathbf{t}$} & \multirow{3}{*}{$\mathrm{df}$} & \multirow{3}{*}{$\begin{array}{c}\text { Sig. } \\
\text { (2-tailed) }\end{array}$} \\
\hline & & \multirow[t]{2}{*}{ Mean } & \multirow{2}{*}{$\begin{array}{c}\text { Std. } \\
\text { Deviation }\end{array}$} & \multirow{2}{*}{$\begin{array}{l}\text { Std. Error } \\
\text { Mean }\end{array}$} & \multicolumn{2}{|c|}{$\begin{array}{l}\text { 95\% Confidence Interval of } \\
\text { the Difference }\end{array}$} & & & \\
\hline & & & & & Lower & Upper & & & \\
\hline Pair 1 & Online Posttest - Online Pretest & 1.200 & 7.153 & 1.847 & -2.761 & 5.161 & 0.650 & 14 & 0.526 \\
\hline Pair 2 & F2F_PostTest - F2F_PreTest & 3.600 & 5.902 & 1.524 & 0.332 & 6.868 & 2.363 & 14 & 0.033 \\
\hline Pair 3 & Blended_PostT - Blended_PreT & 4.667 & 3.457 & 0.893 & 2.752 & 6.581 & 5.228 & 14 & 0.000 \\
\hline
\end{tabular}

Significance level $\mathrm{p}<0.005$.

Table 5. Paired mean results for the three groups of performance in 2020.

\begin{tabular}{|c|c|c|c|c|c|c|c|c|c|}
\hline & & \multicolumn{5}{|c|}{ Paired Differences } & \multirow{3}{*}{$\mathrm{t}$} & \multirow{3}{*}{ df } & \multirow{3}{*}{$\begin{array}{c}\text { Sig. } \\
\text { (2-tailed) }\end{array}$} \\
\hline & & \multirow{2}{*}{ Mean } & \multirow{2}{*}{$\begin{array}{c}\text { Std. } \\
\text { Deviation }\end{array}$} & \multirow{2}{*}{$\begin{array}{l}\text { Std. Error } \\
\text { Mean }\end{array}$} & \multicolumn{2}{|c|}{$\begin{array}{l}95 \% \text { Confidence Interval of } \\
\text { the Difference }\end{array}$} & & & \\
\hline & & & & & Lower & Upper & & & \\
\hline Pair 1 & Online Posttest - Online Pretest & 2.000 & 3.891 & 1.005 & -0.155 & 4.155 & 1.991 & 14 & 0.066 \\
\hline Pair 2 & F2F_PostTest - F2F_PreTest & 3.667 & 3.867 & 0.998 & 1.525 & 5.808 & 3.673 & 14 & 0.003 \\
\hline Pair 3 & Blended_PostT - Blended_PreT & 5.067 & 2.604 & 0.672 & 3.625 & 6.509 & 7.536 & 14 & 0.000 \\
\hline
\end{tabular}

Significance level $\mathrm{p}<0.005$. 
Table 6. Overall paired mean results for the three groups from 2017-2020.

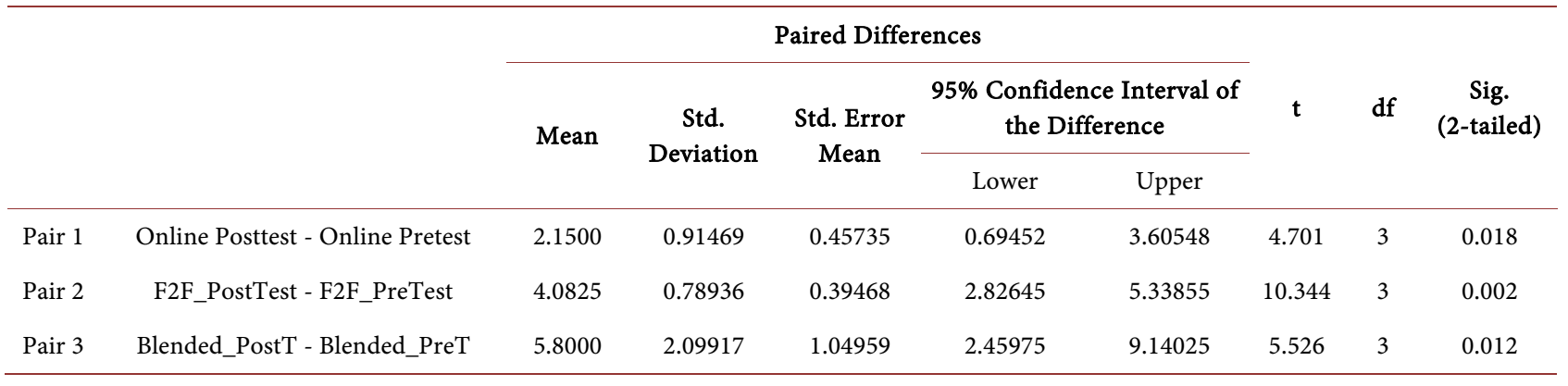

Significance level $\mathrm{p}<0.005$.

\section{Conclusions}

The findings of the study provide evidence to support the fact that the blended mode can be successfully used to support students to improve their business communication skills, especially the presentation skills. This could be due to, as Wang [60] says, the blended learning method provides more opportunities for acquiring new knowledge, sub-skills, and successful learning habits.

Although the sample chosen for the present study is limited to 45 , the results of this study will be of use to the authorities of Higher Educational Institutes including Universities that expect to commence or continue Business Communication courses with blended mode of delivery. In addition, through the findings of this study, the future adult students who wish to upgrade their presentation skills by following a Business English course in the blended mode would be benefitted. The same study can be replicated in a different setting at a different time or for different subjects in order to compare the outcome of different pedagogies.

Raw data were generated at the University of Sri Jayewardenepura in Sri Lanka. Derived data supporting the findings of this study are available from the corresponding authors on request.

\section{Conflicts of Interest}

The authors declare no conflicts of interest.

\section{References}

[1] Lizzio, A., Wilson, K. and Simons, R. (2002) University Students' Perceptions of the Learning Environment and Academic Outcomes: Implications for Theory and Practice. Studies in Higher Education, 27, 27-52. https://doi.org/10.1080/03075070120099359

[2] Garson, G. (1998) Evaluating and Implementation of Web-Based Teaching in Political Science. Political Science and Politics, 31, 585-590. https://doi.org/10.1017/S1049096500054949

[3] Driscoll, E. (2011) Um, Like, Whatever: College Grads Lack Verbal Skills for Business.

https://www.foxbusiness.com/features/um-like-whatever-college-grads-lack-verbal- 
$\underline{\text { skills }}$

[4] Robles, M.M. (2012) Executive Perceptions of the Top 10 Soft Skills Needed in Today's Workplace. Business and Professional Communication Quarterly, 75, 453-465. https://doi.org/10.1177/1080569912460400

[5] Graduate Management Admission Council (2017) Market Intelligence Corporate Recruiters Survey Report 2017. https://www.gmac.com/-/media/files/gmac/research

[6] Russell, J., Russell, B. and Tastle, W.J. (2005) Teaching Soft Skills in a Systems Development Capstone Class. Information Systems Education Journal, 3, 3-19.

[7] Gallup-Lumina Foundation (2014) The 2013 LUMINA Study of the American Public's Opinion on Higher Education and U.S. Business Leaders Poll on Higher Education: What America Needs to Know about Higher Education Redesign.

https://www.luminafoundation.org/files/resources/2013-gallup-luminafoundation-r eport.pdf

[8] Du-Babcock, B. (2006) Teaching Business Communication: Past, Present, and Future. The Journal of Business Communication, 43, 253-264. https://doi.org/10.1177/0021943606288775

[9] Russ, T.L. (2009) The Status of the Business Communication Course at U.S. Colleges and Universities. Business Communication Quarterly, 72, 395-413. https://doi.org/10.1177/1080569909349524

[10] Nealy, C. (2005) Integrating Soft Skills through Active Learning in the Management Classroom. Journal of College Teaching \& Learning, 2, 1-6. https://doi.org/10.19030/tlc.v2i4.1805

[11] Ortiz, L.A., Region-Sebest, M. and MacDermott, C. (2016) Employer Perceptions of Oral Communication Competencies Most Valued in New Hires as a Factor in Company Success. Business and Professional Communication Quarterly, 79, 317-330. https://doi.org/10.1177/2329490615624108

[12] Mitchell, G.W., Skinner, L.B. and White, B.J. (2010) Essential Soft Skills for Success in the Twenty-First Century Workforce as Perceived by Business Educators. Delta Pi Epsilon Journal, 52, 43-53.

[13] Lunenburg, F.C. and Ornstein, A.O. (2008) Educational Administration: Concepts and Practices. Wadsworth, Thousand Oaks.

[14] Chang, H., Park, P. and Cho, S. (2018) An Analysis of Business Communication Courses in Business Schools and Suggestions for Business Communication Research and Curriculum Development. Practice, 1, 33-40.

https://doi.org/10.22682/bcrp.2018.1.1.33

[15] Lee, Y.S. (2020) Instructional Innovations with Business Communication in Classrooms: Practice-Based Presentation Topics and Online Communication Tools. Business Communication Research and Practice, 3, 53-59. https://doi.org/10.22682/bcrp.2020.3.1.53

[16] Young, M. and Murphy, W. (2003) Integrating Communications Skills into the Marketing Curriculum: A Case Study. Journal of Marketing Education, 25, 57-70. https://doi.org/10.1177/0273475302250574

[17] NACE Job Outlook Survey (2017) Naceweb.org. http://www.naceweb.org/about-us/press/2017/the-key-attributes-employers-seek-o n-students-resumes

[18] Chen, X.P., Yao, X. and Kotha, S. (2009) Entrepreneur Passion and Preparedness in Business Plan Presentations: A Persuasion Analysis of Venture Capitalists' Funding Decisions. Academy of Management Journal, 52, 199-214. 
https://doi.org/10.5465/amj.2009.36462018

[19] Sampath, D. and Zalipour, A. (2010) Effective Teaching Strategies for Learners of Business Communication: A Case Study from INTI University College, Malaysia. Intercultural Communication Studies, 19, 256-266.

[20] Dudley-Evans, T. and John, M.J. (2000) Developments in English for Specific Purposes. Cambridge University Press, Cambridge.

[21] Morley, L. (2001) Producing New Workers: Quality, Equality and Employability in Higher Education. Quality in Higher Education, 7, 131-138.

https://doi.org/10.1080/13538320120060024

[22] Xu, Q., Suhadolc, S., Chen, S. and Wang, J. (2021) Characteristics and Effectiveness of Teacher Feedback on Online Business English Oral Presentations. The Asia-Pacific Education Researcher. https://doi.org/10.1007/s40299-021-00595-5

[23] Csikosovaa, A., Senovab, A. and Culkovac, K. (2012) Improving of Communication and Presentation Skills of the University Students through e-Learning. Procedia-Social and Behavioral Sciences, 46, 2847-2851.

https://doi.org/10.1016/j.sbspro.2012.05.575

[24] Dunbar, N.E., Brooks, C.F. and Kubicka-Miller, T. (2006) Oral Communication Skills in Higher Education: Using a Performance-Based Evaluation Rubric to Assess Communication Skills. Innovative Higher Education, 31, 115-128. https://doi.org/10.1007/s10755-006-9012-x

[25] Bower, M., Cavanagh, M., Moloney, R. and Dao, M. (2011) Developing Communication Competence Using an Online Video Reflection System: Pre-Service Teachers' Experiences. Asia-Pacific Journal of Teacher Education, 39, 311-326. https://doi.org/10.1080/1359866X.2011.614685

[26] Raybould, J. and Sheedy, V. (2005) Are Graduates Equipped with the Right Skills in the Employability Stakes? Industrial and Commercial Training, 37, 259-263. https://doi.org/10.1108/00197850510609694

[27] Hutchinson, D. (2007) Teaching Practices for Effective Cooperative Learning in an Online Learning Environment (OLE). Journal of Information Systems Education, 18, 357-367.

[28] Chan, V. (2011) Teaching Oral Communication in Undergraduate Science: Are We Doing Enough and Doing It Right? Journal of Learning Design, 4, 71-79.

https://doi.org/10.5204/jld.v4i3.82

[29] Murillo-Zamorano, L.R. and Montanero, M. (2018) Oral Presentations in Higher Education: A Comparison of the Impact of Peer and Teacher Feedback. Assessment and Evaluation in Higher Education, 43, 138-150. https://doi.org/10.1080/02602938.2017.1303032

[30] Murphy, H., Hildebrandt, H. and Thomas, J. (1997) Effective Business Communications. McGraw-Hill/Irwin, New York.

[31] Ober, S. (2001) Contemporary Business Communication. Houghton Mifflin, Boston.

[32] Roebuck, D. (2001) Improving Business Communication Skills. Prentice-Hall, Upper Saddle River.

[33] Hanna, M. and Wilson, G. (1998) Communicating in Business and Professional Settings. The McGraw-Hill Companies, New York.

[34] Hynes, G. (2005) Managerial Communications: Strategies and Applications. McGraw-Hill/Irwin, New York. 
[35] Argenti, P. (2007) Corporate Communication. McGraw-Hill/Irwin, New York.

[36] Conrad, D. and Newberry, R. (2011) 24 Business Communication Skills: Attitudes of Human Resource Managers versus Business Educators. American Communication Journal, 13, 4-23.

[37] Linardopoulos, N. (2010) Teaching and Learning Public Speaking Online. MERLOT Journal of Online Learning and Teaching, 6, 198-209. http://jolt.merlot.org/vol6nol/linardopoulos 0310.htm

[38] De Grez, L., Valcke, M. and Roozen, I. (2009) The Impact of an Innovative Instructional Intervention on the Acquisition of Oral Presentation Skills in Higher Education. Computers \& Education, 53, 112-120. https://doi.org/10.1016/j.compedu.2009.01.005

[39] Kenkel, C.S. (2011) Teaching Presentation Skills in Online Business Communication Courses. MERLOT Journal of Online Learning and Teaching, 7, 412-418. http://jolt.merlot.org/vol7no3/kenkel 0911.htm

[40] Allen, I.E. and Seaman, J. (2010) Learning on Demand: Online Education in the United States, 2009. Babson Survey Research Group, Babson Park. http://www.sloanconsortium.org/publications/survey/pdf/learningondemand.pdf

[41] Wijewardene, L. (2021) Crisis Education: Adapting to a New Normal Method of Delivery Due to the Covid-19 Pandemic. International Journal of Engineering Science Invention (IJESI), 10, 24-27. http://www.ijesi.org

[42] Yu, L. (2002) Adopting an Online Multimedia Assisted Language Learning Package to Support an English for Academic Purposes (EAP) Course. Information Technology and Universities in Asia: An International Conference (ITUA 2002), Bangkok, 425.

[43] Ephraim Okoro, E., Washington, M.C. and Otis Thomas, O. (2017) The Impact of Interpersonal Communication Skills on Organizational Effectiveness and Social Self-Efficacy: A Synthesis. International Journal of Language and Linguistics, 4, 28-32.

[44] Ducoffe, R. and Ducoffe, S. (1990) Tips from Top Advertising Executives: Implications for Advertising Education. Journal of Marketing Education, 12, 52-58. https://doi.org/10.1177/027347539001200108

[45] Brun, J.P. (2010) Missing Pieces: 7 Ways to Improve Employee Well-Being and Organizational Effectiveness. Palgrave Macmillan, New York.

[46] Wilson, D. (2005) New Perspectives in Applied Communication. Sterlin-Hordan Publishers Workforce-Skills Preparedness Report, Ibadan.

[47] Job Outlook 2016: The Attributes Employers Want to See on New College Graduates Resumes, National Association of Colleges and Employers (NACE) 2016.

[48] Crosthwaite, P., Sanhueza, A.G. and Schweinberger, M. (2021) Training Disciplinary Genre Awareness through Blended Learning: An Exploration into EAP Students' Perceptions of Online Annotation of Genres across Disciplines. Journal of English for Academic Purposes, 53, Article ID: 101021.

https://doi.org/10.1016/j.jeap.2021.101021

[49] Campbell, K., Mothersbaugh, D., Brammer, C. and Taylor, T. (2001) Peer versus Self-Assessment of Oral Business Presentation Performance. Business Communication Quarterly, 64, 23-42. https://doi.org/10.1177/108056990106400303

[50] Grez, L., Valcke, M. and Roozen, I. (2009) The Impact of an Innovative Instructional Intervention on the Acquisition of Oral Presentation Skills in Higher Education. Computers \& Education, 53, 112-120. 
https://doi.org/10.1016/j.compedu.2009.01.005

[51] Kennedy, R. (2007) In-Class Debates: Fertile Ground for Active Learning and the Cultivation of Critical Thinking and Oral Communication Skills. International Journal of Teaching and Learning in Higher Education, 19, 183-190.

[52] Cronin, M. and Glenn, P. (1991) Oral Communication across the Curriculum in Higher Education: The State of the Art. Communication Education, 40, 356-367. https://doi.org/10.1080/03634529109378860

[53] Graham, C.R. (2006) Blended Learning Systems: Definition, Current Trends, and Future Directions. In: Bonk, C.J. and Graham, C.R., Eds., The Handbook of Blended Learning. Global Perspectives, Pfeiffer Publishing, San Francisco, 3-21.

[54] Poon, J. (2013) Blended Learning: An Institutional Approach for Enhancing Students' Learning Experiences. Journal of Online Learning and Teaching, 9, 271-288.

[55] Friesen, N. (2012) Report: Defining Blended Learning.

[56] Joseph, S. and Sherine, A. (2019) Blended Learning an Effective Tool to Teach Presentation Skills. International Journal of Engineering and Advanced Technology, 9, 962. https://doi.org/10.35940/ijeat.A9448.109119

[57] The University of Central Florida (2015) Benefits of Blended Learning.

[58] Bohme, K. (2009) Web-Based Rhetorical Training-A Virtual Impossibility? Problems and Perspectives of Improving Public Speaking Skills in Virtual Learning Environments. Journal of Education, Informatics, and Cybernetics, 1, 1-6. http://www.journaleic.com/article/download/3460/2595

[59] Banditvilai, C. (2016) Enhancing Students' Language Skills through Blended Learning. The Electronic Journal of e-Learning, 14, 220-229.

[60] Wang, Y., Grant, S. and Grist, M. (2021) Enhancing the Learning of Multi-Level Undergraduate Chinese Language with a 3D Immersive Experience-An Exploratory Study. Computer Assisted Language Learning, 34, 114-132. https://doi.org/10.1080/09588221.2020.1774614

[61] Bazelais, P., Doleck, T. and Lemay, D.J. (2018) Investigating the Predictive Power of TAM: A Case Study of CEGEP Students' Intentions to Use Online Learning Technologies. Education and Information Technologies, 23, 93-111. https://doi.org/10.1007/s10639-017-9587-0

[62] Dharmawardene, R.P. (2019) Using Enriched Virtual Mode to Teach English Grammar. Proceedings of the 6th International Conference on Multidisciplinary Approaches, Colombo, 12 March 2019, 84.

https://papers.ssrn.com/sol3/papers.cfm?abstract id=3497365 